\title{
PENINGKATAN HASIL BELAJAR MATEMATIKA TENTANG PECAHAN MELALUI PENDEKATAN MATEMATIKA REALISTIK
}

\author{
Ratih Purnamasari \\ Guru SDN Cilendek Timur \\ RatihPur@Yahoo.com
}

\begin{abstract}
The aim of this research is to improve the student mathematic result about fraction through realistic approach. This research is held in SDN Cilendek Timur 2 Bogor with 24 people as a subject of this research. The method that used was called class action research method with Kemmis and Taggart Model. This method was divided into planning, action, observation, and reflection. This research was carried out in three cycles. The first and second cycle consist of two meetings and for third cycle is for one meeting. The data was collected by test, interview, notes, and documentation. The result of this research show that there was improvement for students score for fraction. At first cycle, the percentage of number of student who have score 70 or more was around $12,5 \%$. At second cycle, it would be $56,5 \%$, and for third, it reached to $92 \%$. Teacher and student activity that used by this approach was reached to $95 \%$ at the end of third cycle. So, we can make conclusion that realistic approach can improve student for their mathematic test of fraction. Therefore, I suggest that teacher has to try this approaching in their mathematic class as an alternative to improve their students skill, especially for fraction. In order to get good result in process, teacher also has to make students into group, arrange the contextual problems that students found in their life, provide some properties, and guide students while they was trying to solve their problems that we give.
\end{abstract}

Keyword: learning result, class action research, realistic mathematic education

\begin{abstract}
Abstraksi: Tujuan dari penelitian ini adalah untuk meningkatkan siswa hasil matematika tentang pecahan melalui pendekatan realistis. Penelitian ini dilaksanakan di SDN Cilendek Timur 2 Bogor dengan 24 orang sebagai subjek penelitian ini. Metode yang digunakan disebut metode penelitian tindakan kelas dengan Kemmis dan Taggart Model. Metode ini dibagi ke dalam perencanaan, tindakan, observasi, dan refleksi. Penelitian ini dilakukan dalam tiga siklus. Siklus pertama dan kedua terdiri dari dua pertemuan dan untuk siklus ketiga adalah untuk satu pertemuan. Pengumpulan data dilakukan dengan tes, wawancara, catatan, dan dokumentasi. Hasil penelitian ini menunjukkan bahwa ada peningkatan untuk mencetak siswa untuk fraksi. Pada siklus pertama, persentase jumlah siswa yang memiliki skor 70 atau lebih adalah sekitar 12,5\%. Pada siklus kedua, itu akan menjadi 56,5\%, dan untuk ketiga, mencapai 92\%. Guru dan aktivitas siswa yang digunakan oleh pendekatan ini mencapai $95 \%$ pada akhir siklus ketiga. Jadi, kita dapat membuat kesimpulan bahwa pendekatan yang realistis dapat meningkatkan siswa untuk tes matematika mereka fraksi. Oleh karena itu, saya menyarankan bahwa guru harus mencoba ini mendekati dalam kelas matematika mereka sebagai alternatif untuk meningkatkan keterampilan siswa mereka, terutama untuk fraksi. Untuk mendapatkan hasil yang baik dalam proses, guru juga harus membuat siswa ke dalam kelompok, mengatur masalah kontekstual bahwa siswa ditemukan dalam kehidupan mereka, memberikan beberapa sifat, dan membimbing siswa saat mereka sedang berusaha untuk memecahkan masalah mereka yang kita berikan.
\end{abstract}

Kata kunci: hasil belajar, penelitian tindakan kelas, pendidikan matematika realistik 
Matematika merupakan ilmu universal yang mempunyai peran penting dalam berbagai disiplin dan memajukan daya pikir manusia. Perkembangan pesat disegala bidang dilandasi oleh perkembangan matematika. Mata pelajaran matematika perlu diberikan kepada semua peserta didik mulai dari Sekolah Dasar (SD) untuk membekali peserta didik dengan kemampuan berpikir logis, analitis, sistematis, kritis, dan kreatif, serta kemampuan bekerjasama. Kompetensi tersebut diperlukan agar peserta didik dapat memiliki kemampuan memperoleh, mengelola, dan memanfaatkan informasi untuk bertahan hidup pada keadaan yang selalu berubah, tidak pasti, dan kompetitif.

Akan tetapi dalam pembelajaran di sekolah, meski telah banyak upaya yang dilakukan oleh para pakar pendidikan, ternyata pembelajaran matematika di Indonesia sampai saat ini masih memiliki banyak permasalahan. Salah satu masalah itu adalah matematika sering dianggap sebagai mata pelajaran yang sulit bagi siswa. Efek negatif dari pandangan ini adalah ada banyak siswa yang sudah merasa antipati dengan matematika sebelum mereka betul-betul mempelajari matematika.

Dalam Kurikulum Tingkat Satuan Pendidikan (KTSP) untuk mata pelajaran matematika kelas satu sampai kelas enam, terdapat begitu banyak Kompetensi Dasar (KD) yang harus dikuasai oleh siswa. Dari sekian banyak KD yang ada, menurut hasil wawancara terhadap seorang guru kelas IV di SDN Cilendek Timur 2 Bogor, KD tentang pecahan merupakan salah satu dari konsep yang sulit dipahami oleh siswa. Dari 25 orang siswa yang beliau ajar, hanya sekitar lima orang saja yang betul-betul bisa memahami meski sudah diajarkan secara berulang-ulang, dan bila diberi tes baik ulangan harian maupun pada Ujian Tengah Semester (UTS) dan Ujian Akhir Semester (UAS) lebih dari setengah jumlah siswa hasilnya berada di bawah Kriteria Ketuntasan Minimal (KKM) yang diharapkan.

Ternyata hal itu juga sejalan dengan hasil wawancara secara acak terhadap 30 guru kelas IV di 30 Sekolah Dasar yang ada di kabupaten dan kota Bogor. Dari survei didapatkan data bahwa hampir semua guru menyatakan, KD tentang pecahan sulit dipahami oleh sebagian besar siswanya. Ada banyak faktor yang menyebabkan sulitnya siswa dalam memahami KD tentang pecahan. Dari sekian banyak faktor penyebab, faktor guru dinilai paling dominan diantara faktor-faktor yang lain. Karena disadari atau tidak, terlepas dari keterbatasan yang ada, guru adalah ujung tombak dari tujuan pendidikan.

Berkaitan dengan tugas seorang guru yang dominan dalam pembelajaran, harus diakui, meski KTSP sudah mengamanatkan agar dalam setiap kesempatan, pembelajaran 
Peningkatan Hasil Belajar Matematika Tentang Pecahan Melalui Pendekatan Matematika Realistik

Ratih Purnamasari

matematika hendaknya dimulai dengan pengenalan masalah yang sesuai dengan situasi (contextual problem), memperhatikan perkembangan siswa, guru sebagai fasilitator dan siswa diajak untuk menemukan konsepnya sendiri, pada kenyataannya berdasarkan penemuan di lapangan, para guru sampai hari ini masih aman dengan pendekatan teacher center. Metode yang digunakan pun baik dalam membelajarkan pecahan maupun konsep yang lain hanya berkutat pada ceramah dan ekspositori. Akibatnya siswa tidak mampu menemukan konsepnya sendiri. Ia tidak mampu menghubungkan antara konsep pecahan dengan kehidupan sehari-hari. Siswa hanya tahu hitung-hitungannya tanpa menyadari untuk apa ia belajar pecahan. Guru terlalu abstrak dalam membelajarkan konsep pecahan pada siswa. Guru hanya membelajarkan konsep pecahan sebagai simbol-simbol yang miskin makna dan pesan sehingga informasi yang ingin disampaikan oleh matematika melalui konsep pecahan tidak mampu menjangkau pikiran siswa.

Konsep pecahan selalu langsung dibelajarkan dengan cara-cara formal yang boleh jadi mereka bisa mengerjakan soal di kelas tetapi tidak mampu menggunakannya pada kehidupan sehari-hari. Contohnya pada operasi bilangan perkalian pecahan siswa diajarkan untuk menyelesaikan dengan mengalikan pembilang dengan pembilang dan penyebut dengan penyebut dan pada operasi pembagian pecahan siswa diajarkan menyelesaikan soal dengan membalik posisi penyebut dan pembilang pembagi. Begitupula pada penjumlahan dan pengurangan pecahan siswa diajarkan menyelesaikan soal dengan penyebut berbeda agar menyamakan dahulu penyebutnya, sedangkan yang penyebutnya sudah sama siswa diajarkan untuk langsung menjumlahkan atau mengurangkan pembilangnya. Cara-cara yang digunakan tersebut barangkali bisa dipahami oleh siswa yang memang memiliki kecerdasan matematika tinggi karena siswa hanya harus mengahafal langkah. Namun banyak diantara mereka tidak memahami makna dibalik caracara itu. Mengapa ini dan mengapa itu? Sehingga pemahaman mereka berhenti hanya sampai pada paham prosedur saja.

Oleh sebab itu, dalam pembelajaran matematika khususnya tentang pecahan perlu ada upaya penerapan pendekatan pembelajaran yang tepat agar siswa tidak lagi merasa sulit apalagi takut pada matematika. Pendekatan itu harus dapat membuat pembelajaran menjadi bermakna serta harus menjamin bahwa konsep-konsep matematika tidak lahir dari penjelasan guru akan tetapi lahir dari pemikiran-pemikiran siswa (re-invent), 
sehingga siswa mampu menerapkan konsep matematika dalam kehidupan sehari-hari.

Salah satu pendekatan matematika yang saat ini sedang marak dibicarakan orang mampu membuat siswa menemukan konsepnya sendiri adalah pembelajaran dengan menggunakan pendekatan matematika realistik. Kebermaknaan konsep matematika merupakan konsep utama dari pendekatan matematika realistik. Proses belajar siswa hanya akan terjadi jika pengetahuan (knowledge) yang dipelajari bermakna bagi siswa. Suatu pengetahuan akan menjadi bermakna bagi siswa jika proses pembelajaran dilaksanakan dalam suatu konteks atau permasalahan realistik. Suatu masalah realistik tidak harus selalu berupa masalah yang ada di dunia nyata (real world problem) dan bisa ditemukan dalam kehidupan sehari-hari siswa. Suatu masalah disebut "realistik" jika masalah tersebut dapat dibayangkan (imagineable) atau nyata (real dalam pikiran siswa).

Perhatian pada pengetahuan informal (informal knowledge) yang dimiliki siswa menjadi hal yang sangat mendasar dalam mengembangkan permasalahan yang realistik. Pengetahuan informal siswa dapat berkembang menjadi suatu pengetahuan formal (matematika) melalui proses pemodelan.

Beberapa penelitian pendahuluan di beberapa Negara menunjukkan bahwa pembelajaran menggunakan pendekatan realistik dapat membuat matematika menjadi lebih menarik, relevan, dan bermakna, tidak terlalu formal dan tidak terlalu abstrak. Pembelajaran realistik juga sangat mempertimbangkan tingkat kemampuan siswa, menekankan belajar matematika pada "learning by doing", memfasilitasi penyelesaian masalah matematika dengan tanpa menggunakan penyelesaian (algoritma) yang baku serta menggunakan konteks sebagai titik awal pembelajaran matematika.

Melihat keberhasilan yang telah diraih di negara lain, tentu tidak ada salahnya apabila pendekatan realistik diterapkan dalam pembelajaran matematika tentang pecahan di Indonesia khususnya di SDN Cilendek Timur 2 Bogor. Oleh karena itu penelitian ini diberi judul "Peningkatan Hasil Belajar Matematika Tentang Pecahan Melalui Pendekatan Matematika Realistik di Kelas IV SDN Cilendek Timur 2 Bogor".

Berbagai definisi dikemukakan oleh para pakar tentang apa yang dimaksud dengan Penelitian Tindakan Kelas (PTK). Kemmis dan Carr dalam Kasihani Kasbolah (1998/1999: 13) mengemukakan bahwa penelitian tindakan merupakan suatu bentuk penelitian yang bersifat reflektif yang dilakukan oleh pelaku dalam masyarakat sosial dan bertujuan untuk memperbaiki pekerjaannya, memahami pekerjaan ini serta situasi dimana pekerjaan ini dilakukan. Meski 
Peningkatan Hasil Belajar Matematika Tentang Pecahan Melalui Pendekatan Matematika Realistik Ratih Purnamasari

pada awalnya Kemmis dan Carr hanya menekankan perlunya penelitian tindakan di bidang sosial secara umum namun dalem penjelasan berikutnya Kemmis dan Carr memasukkan bidang pendidikan di dalamnya. Hal ini berarti guru pun diharapkan menjadi bagian dari masyarakat yang melakukan penelitian tindakan, khususnya di kelas yang menjadi tempat guru mengajar. Ebbut berpendapat bahwa penelitian tindakan merupakan studi yang sistematis yang dilakukan dalam upaya memperbaiki praktikpraktik dalam pendidikan dengan melakukan tindakan praktis serta refleksi dari tindakan tersebut. Kata sistematis dalam pendapat Ebbut mengindikasikan bahwa penelitian pendidikan kelas merupakan suatu rangkaian yang didalamnya terdapat tindakan. Sedangkan kata refleksi mengindikasikan bahwa penelitian tindakan tidak dilakukan sekali melainkan berulang-ulang sampai diperoleh hasil yang diharapkan. John Elliot dalam David Hopkins (2007: 88) mengatakan bahwa penelitian tindakan dapat didefinisikan sebagai penelitian terhadap situasi sosial dengan tujuan meningkatkan kualitas tindakan di dalamnya. Penelitian ini bertujuan untuk memberikan pertimbangan praktis tentang situasi-situasi konkret, dan validasi teori-teori atau hipotesis-hipotesis yang dihasilkannya tidak bergantung pada uji kebenaran "saintis", karena tujuan utamanya adalah membantu masyarakat agar dapat bertindak lebih cerdas dan mahir.

Sebelum masuk ke pemahaman tentang hasil belajar ada baiknya dibahas terlebih dahulu pengertian dari belajar sehingga menjadi jelas hal apa saja yang seharusnya dihasilkan dari proses belajar. Ada banyak definisi tentang belajar. Skinner dalam Dimyati dan Mudjiono (2009: 9) berpandangan bahwa belajar adalah suatu perilaku. Pada saat orang belajar, maka responnya menjadi lebih baik. Sebaliknya, bila ia tidak belajar maka responnya menurun. Respon itulah yang dimaksudkan oleh Skinner sebagai perilaku. Menurut teori ini sebelum mengajar guru harus mencari dan menemukan perilaku siswa yang positif atau negatif, membuat daftar penguat positif, memilih dan menentukan urutan tingkah laku yang dipelajari serta penguatnya, kemudian guru membuat program pembelajaran.

Dari pendapat di atas dapat disimpulkan bahwa belajar adalah suatu aktivitas mental/psikis yang berlangsung dalam interaksi aktif dengan lingkungan yang menghasilkan perubahan perilaku berupa informasi verbal, keterampilan intelek, keterampilan motorik, sikap, dan siasat kognitif yang bersifat relatif konstan dan berbekas. 
Belajar sebagai suatu aktivitas menghendaki adanya sesuatu yang dicapai atau didapatkan setelah proses belajar selesai yaitu berupa hasil belajar. Tanpa adanya hasil belajar maka proses belajar dikatakan tidak efektif. Becker dan Selter (2003: 143) menyatakan pendidikan matematika realistik atau Realistic Mathematic Education (RME) diketahui sebagai pendekatan yang telah berhasil di Netherlands. Freudenthal, Gravenmeijer, dan Streefland menyatakan gagasan pendekatan pembelajaran matematika realistik ini tidak hanya popular di negeri Belanda saja, melainkan banyak mempengaruhi kerja para pendidik matematika dibanyak bagian dunia. Pendidikan Matematika Realistik Indonesia (PMRI) tidak dapat dipisahkan dari institude Freudenthal. Institut ini didirikan pada tahun 1971, berada di bawah Utrecht University Belanda. Nama institut diambil dari nama pendirinya yaitu Profesor Hans Freudenthal, seorang penulis, pendidik dan matematikawan berkebangsaan Jerman-Belanda. Sejak tahun 1971, Institut ini mengembangkan suatu pendekatan teoritis terhadap pembelajaran matematika yang dikenal dengan RME (Realistic Mathematics Education). Hal senada juga dikemukkan oleh Marja van den Heuvel-Panhuizen (2000:3) dalam karya mereka yang berjudul "Mathematics education in the Netherlands: A guided tour" disebutkan bahwa perkembangan apa yang sekarang dikenal sebagai RME dimulai sekitar 1970. Pondasi yang diletakkan oleh Freudental dan rekan-rekannya di IOWO, pendahulu tertua dari Freudental Institut. Dorongan sebenarnya untuk gerakan reformasi berawal pada tahun 1968 dari proyek Wiskobas, diprakarsai oleh Wijdeveld dan Goffree. Hans Freudental mengatakan "mathematics is a human activity", matematika bukanlah satu kumpulan aturan atau sifat-sifat yang sudah lengkap yang harus siswa pelajari, matematika bukan merupakan suatu subjek yang siap saji untuk siswa, melainkan suatu pelajaran yang dinamis yang dapat dipelajari dengan dengan cara mengerjakannya. Menurut freudental pembelajaran matematika seharusnya tidak seperti yang selama ini terjadi di lembaga pendidikan yang lebih menjadikan matematika sebagai informasi yang wajib disampaikan, namun siswa tidak mengerti darimana dan bagaimana matematika itu ada. Idealnya, siswa haruslah dipahamkan bagaimana matematika ada.

Marja van den Heuvel-Panhuizen mengatakan bahwa The present form of $R M E$ has been mostly determined by Freudenthal's (1977) view on mathematics. He felt mathematics must be connected to reality, stay close to children's experience and be relevant to society, in order to be of human value. Instead of seeing mathematics as a subject to 
Peningkatan Hasil Belajar Matematika Tentang Pecahan Melalui Pendekatan Matematika Realistik Ratih Purnamasari

be transmitted, Freudenthal stressed the idea of mathematics as a human activity. Mathematics lessons should give students the 'guided' opportunity to 're-invent' mathematics by doing it. This means that in mathematics education, the focal point should not be on mathematics as a closed system but on the activity, on the process of mathematization (Freudenthal, 1968).

Bentuk dari RME telah sebagian besar ditentukan oleh pandangan Freudental tentang matematika. Freudental merasa matematika harus dihubungkan dengan kenyataan, tetap dekat dengan pengalaman anak dan relevan dengan masyarakat. Freudental menekankan ide manusia sebagai aktivitas manusia. Matematika harus memberikan kesempatan kepada siswa untuk menemukan kembali matematika (re-invent).

\section{METODE}

Metode penelitian yang digunakan adalah metode penelitian Tindakan Kelas (PTK). Langkah-langkah yang dilakukan dalam PTK adalah (1). mengidentifikasi masalah, (2) melakukan analisis masalah, (3) merumuskan masalah, hipotesis tindakan, dan (5) melaksanakan tindakan.

Desain penelitian tindakan kelas menurut model Kemmis dan Tagart merupakan suatu siklus yang terdiri dari tahap-tahap : a). perencanaan (planning), b). tindakan (acting), c). observasi (observing), dan d). refleksi (reflecting). Sebelum peneliti melakukan tindakan terlebih dahulu harus direncanakan secara seksama jenis tindakan yang akan dilakukan. Kedua, setelah rencana disusun secara matang, barulah tindakan itu dilakukan. Ketiga, bersamaan dengan dilaksanakannnya tindakan, peneliti mengamati proses pelaksanaan tindakan itu sendiri dan akibat yang ditimbulkannya. Keempat, berdasarkan hasil pengamatan tersebut, peneliti kemudian melakukan refleksi atas tindakan yang telah dilakukan. Jika hasil refleksi menunjukkan perlu dilakukan perbaikan atas tindakan yang telah dilakukan, maka rencana tindakan perlu disempurnakan lagi agar tindakan yang dilaksanakan berikutnya tidak sekedar mengulang dari apa yang telah diperbuat sebelumnya. Demikian seterusnya sampai masalah yang diteliti dapat dipecahkan secara optimal.

\section{HASIL}

\section{Siklus I}

Kegiatan pada siklus pertama terdiri atas dua pertemuan. Langkah-langkah yang dibuat meliputi mempersiapkan RPP dengan menggunakan pendekatan matematika realistik, menyiapkan lembar pengamatan aktivitas guru dan siswa, lembar untuk catatan lapangan, lembar kegiatan siswa, lembar 
wawancara dan mempersiapkan media dipelajari, yaitu tentang penjumlahan pecahan. pembelajaran.

Pada tahap pelaksanaan, guru Guru juga tidak lupa menyampaikan tujuan melaksanakan apa yang telah direncanakan dalam RPP. Pertama-tama guru mengucapkan salam dan mengkondisikan siswa, memimpin doa dan mengecek kehadiran siswa. Selanjutnya guru melakukan apersepsi pembelajaran. Dengan arahan guru, siswa membentuk kelompok kecil (6 orang). Siswa menyimak penjelasan tentang alur pembelajaran sesuai dengan pendekatan realistik. Berdasarkan hasil tes siklus I, kemudian menyampaikan topik yang akan diperoleh data sebagai berikut:

Tabel 1 Data hasil tes siklus I

\begin{tabular}{ccc} 
Kriteria & Jumlah siswa & Presentase (\%) \\
\hline$>70$ & 3 & 12,5 \\
\hline$=70$ & 0 & 0 \\
\hline$<70$ & 21 & 87,5
\end{tabular}

Dari tabel di atas, dari hasil tes siklus I diperoleh 3 orang mendapatkan skor melebihi KKM dan 21 orang lagi mendapatkan skor di bawah KKM. Apabila dipresentasikan maka yang memperoleh skor mencapai KKM adalah $12,5 \%$, yang memperoleh skor sama dengan 70 sebanyak $0 \%$, sedangkan sisanya, yaitu yang tidak mencapai KKM adalah 87,5\%.

\section{Siklus II}

Pada siklus II, yang akan dibelajarkan adalah pengurangan pecahan dengan penyebut sama dan penyebut tidak sama. Kegiatan pembelajaran pada siklus II terdiri atas dua pertemuan. Langkah-langkah yang dibuat sama seperti pada siklus pertama, yaitu: meliputi mempersiapkan RPP dengan menggunakan pendekatan matematika realistik, menyiapkan lembar pengamatan aktivitas guru dan siswa, lembar wawancara, lembar untuk catatan lapangan, lembar kegiatan siswa dan mempersiapkan media pembelajaran. Selain itu, hasil refleksi pada siklus I juga dijadikan bahan acuan dalam perbaikan mengajar pada siklus II. Perbaikan dilakukan pada tahapan-tahapan pembelajaran realistik yang masih memiliki kekurangan.

Dalam aspek pemahaman konsep, pada saat berkeliling membimbing kelompok, guru akan mengarahkan siswa untuk mengaitkan konsep pecahan yang sedang dipelajari dengan konsep matematika yang lain dan dengan kehidupan sehari-hari. Misalkan dalam membagi kue tiruan guru memahamkan siswa 
Peningkatan Hasil Belajar Matematika Tentang Pecahan Melalui Pendekatan Matematika Realistik Ratih Purnamasari

bahwa dalam membagi kue harus sama. Supaya sama pada saat membagi, siswa bisa membagi dengan menghitung derajatnya (kue berbentuk lingkaran). Selain itu, masih dalam aspek pemahaman konsep, guru mengkondisikan siswa agar menjelaskan jawaban kelompok dengan bantuan gambar pada papan tulis. Misalnya dengan cara meminta bantuan siswa yang bisa menggambar, untuk menggambarkan jawaban kelompok di papan tulis. Dalam aspek pembagian kelompok siswa terdiri atas siswa pandai dan kurang pandai serta adanya penjelasan di awal pembelajaran tentang tugas-tugas setiap anggota dalam kelompok.
Dalam aspek pengerjaan LKS, guru akan menjelaskan dengan pelan-pelan supaya siswa memahami maksud soal dengan baik dan memberikan kesempatan lebih banyak untuk bertanya dengan memberikan giliran kelompok untuk bertanya. Terakhir dalam aspek presentasi, guru akan menuntun siswa untuk berbicara di depan kelas dan lebih memotivasi siswa untuk bertanya, memberikan pendapat dan menyanggah jawaban teman dengan menunjuk tiap kelompok secara bergiliran dan guru memberikan contoh bagaimana cara melakukannya. Di bawah ini merupakan tabel hasil belajar siswa setelah dilakukan tes siklus II.

Tabel 2 Data hasil tes siklus II

\begin{tabular}{ccc} 
Kriteria & Jumlah siswa & Presentase (\%) \\
\hline$>70$ & 12 & 52,2 \\
\hline$=70$ & 1 & 4,3 \\
\hline$<70$ & 10 & 43,5
\end{tabular}

Dari 23 siswa yang hadir, sebanyak 12 orang memiliki skor lebih dari 70, satu orang memiliki skor 70 dan sisanya mendapatkan skor dibawah 70. Presentase siswa yang mampu mencapai KKM (70) adalah 56,5\% dan yang belum mencapai KKM sebanyak 43,5\%.

\section{Siklus III}

Siklus ketiga terdiri atas satu pertemuan. Pada siklus ketiga ini yang akan dibelajarkan adalah Menyelesaikan masalah (soal) hitung campuran (penjumlahan dan pengurangan pecahan) dalam kehidupan sehari-hari dan menyederhanakan pecahan. Kegiatan pembelajaran pada siklus ke dua terdiri atas satu pertemuan. Langkah-langkah yang dibuat sama seperti pada siklus sebelumnya, yaitu: meliputi mempersiapkan RPP dengan menggunakan pendekatan matematika realistik, menyiapkan lembar pengamatan aktivitas guru dan siswa, lembar 
untuk catatan lapangan, lembar kegiatan siswa, lembar wawancara dan mempersiapkan media pembelajaran. Selain itu, hasil refleksi pada siklus II juga dijadikan bahan acuan dalam perbaikan mengajar pada siklus III.

Pada siklus II, dalam aspek presentasi, guru belum berhasil mengkondisikan siswa agar menjelaskan jawaban kelompok dengan bantuan gambar pada papan tulis. Untuk mensiasati itu maka pada siklus III, guru memotivasi setiap kelompok untuk berusaha menggambar semampunya. Kelompok yang berhasil menggambar dipapan tulis saat mereka ke depan dan menggunakannya untuk menjelaskan jawaban maka akan mendapatkan reward. Untuk mengefektifkan waktu presentasi dibagi dua, pertama semua kelompok menggambar terlebih dahulu di papan tulis. Kedua, dengan bergiliran kelompok menjelaskan jawaban dengan menggunakan gambar yang sudah dibuat. Reward juga berlaku untuk kelompok yang mau bertanya, berpendapat atau menyanggah jawaban temannya yang presentasi. Reward yang diberikan bukan berupa barang melainkan berupa tambahan nilai.

Pembelajaran dilaksanakan sesuai dengan rencana yang telah dibuat sebelumnya. Setelah mengkondisikan siswa, mengecek kehadiran dan melakukan apersepsi, guru kembali menyampaikan topik yang akan dipelajari dan tujuan pembelajaran dengan terlebih dahulu menggali pemahaman siswa tentang topik yang akan dipelajari, kemudian siswa membentuk kelompok kecil (6 orang).

Di bawah ini merupakan tabel hasil belajar siswa setelah dilakukan tes siklus III.

Tabel 3 Data hasil tes siklus III

\begin{tabular}{ccc} 
Kriteria & Jumlah siswa & Presentase (\%) \\
\hline$>70$ & 19 & 79,2 \\
\hline$=70$ & 3 & 12,5 \\
\hline$<70$ & 2 & 8,3
\end{tabular}

Dari tes yang diberikan, tercatat 19 orang mendapatkan skor di atas 70, 3 orang mendapatkan skor sama dengan 70 dan 2 orang mendapatkan skor di bawah 70 . Presentase siswa yang mencapai KKM mencapai $92 \%$.

\section{Hasil Analisis Data}

Pada siklus I, pelaksanaan pembelajaran oleh guru masih memiliki banyak kekurangan. Meski begitu, pada siklus II guru sudah mampu mengoptimalkan kinerjanya yang berimbas pula pada optimalnya keaktifan siswa. Keoptimalan itu makin sempurna 
Peningkatan Hasil Belajar Matematika Tentang Pecahan Melalui Pendekatan Matematika Realistik

Ratih Purnamasari

manakala tindakan telah memasuki siklus III. Peningkatan kinerja guru ternyata berdampak

Pada tabel di atas nampak bahwa pada siklus I guru belum menyediakan alat peraga benda sebenarnya, belum meminta perwakilan kelompok siswa melaporkan jawaban hasil diskusi dengan menggambarnya di papan tulis, belum mengarahkan siswa untuk mengaitkan konsep yang akan dipelajari dengan konsep matematika yang lain, dan belum mengarahkan siswa untuk mengaitkan konsep yang akan dipelajari dengan kehidupan sehari-hari. Pada siklus II guru

Dari tabel di atas terlihat bahwa siswa beraktifitas sesuai dengan apa yang telah dilakukan oleh guru. Misalnya saja ketika guru tidak mengarahkan siswa untuk mengaitkan konsep yang sedang dipelajari dengan konsep matematika yang lain, maka siswa pun tidak melakukannya. Begitupula ketika guru tidak berhasil mengkondisikan positif terhadap keaktifan siswa pada setiap siklusnya.

belum menyediakan alat peraga benda sebenarnya dan belum mampu mengkondisikan agar perwakilan kelompok siswa melaporkan jawaban hasil diskusi dengan menggambarnya di papan tulis. Namun di siklus III guru sudah mampu melaksanakannya. Ternyata hal tersebut di atas berdampak pada keaktifan siswa. Berdasarkan hasil observasi pada siswa dapat terlihat

siswa untuk menjelaskan jawaban dengan menggambar jawaban pada papan tulis, maka siswapun tidak melakukannya. Hal ini juga dapat dilihat apabila dibuat persentase poinpoin yang telah dilaksanakan guru pada lembar observasi dengan poin-poin yang telah dilaksanakan oleh siswa pada setiap siklusnya, sebagai berikut:

Tabel 4 Nilai pengamatan pembelajaran dengan pendekatan realistik pada setiap siklus

\section{Aspek Penilaian}

\section{Presentasi Nilai Perolehan}

\begin{tabular}{lccc}
\multicolumn{1}{c}{ Aspek Penilaian } & Siklus I & Siklus II & Siklus III \\
\cline { 2 - 4 } $\begin{array}{lccc}\text { Aktivitas guru pada pembelajaran } \\
\text { realistik }\end{array}$ & $75 \%$ & $90 \%$ & $95 \%$ \\
\hline $\begin{array}{l}\text { Aktivitas siswa pada pembelajaran } \\
\text { realistik }\end{array}$ & $65 \%$ & $80 \%$ & $90 \%$ \\
\end{tabular}

Berdasarkan grafik di muka, terjadi dari siklus I sampai siklus III. Peningkatan peningkatan aktivitas guru dan siswa mulai yang terjadi rata-rata $7 \%$ untuk guru 
sedangkan untuk siswa rata-rata peningkatan sebesar $8 \%$. Cukup kecil untuk sebuah nilai peningkatan. Meski begitu presentase awal, baik siswa maupun guru menunjukkan kerja yang positif. Terlihat bahwa guru sebelum tindakan berusaha mempersiapkan diri sebaik mungkin sehingga pada siklus I guru sudah mampu mencapai keberhasilan yang cukup tinggi yaitu 75\%. Hal itu juga berdampak pada aktivitas siswa yang sejak siklus I sudah mencapai $65 \%$. Artinya guru sudah berhasil melaksanakan 13 tahapan pembelajaran dari 20 tahapan yang ada pada pembelajaran realistik. Dari tabel di atas dapat terlihat bahwa ketika guru mengalami peningkatan kinerja maka keaktifan siswa juga meningkat. Data ini membuktikan betapa pentingnya peran guru dalam sebuah pembelajaran. Meski begitu guru bukan bertugas mentransfer ilmu melainkan hanya menjadi fasilitator saja. Karena apabila guru menjadi pentransfer ilmu maka keaktifan siswa justru akan menurun.

Selain berpengaruh terhadap keaktifan siswa ternyata peningkatan kinerja guru juga memiliki dampak positif terhadap hasil belajar siswa. Berdasarkan hasil tes pada setiap siklus, hasil belajar siswa tentang pecahan sebagai berikut:

Tabel 5 Data Hasil Belajar Pecahan Siswa Pada Tiap Siklus

\begin{tabular}{|c|c|c|c|c|c|c|c|c|}
\hline \multirow{2}{*}{ Data } & & \multicolumn{2}{|c|}{ Siklus I } & \multicolumn{2}{|c|}{ Siklus II } & \multicolumn{2}{|c|}{ Siklus III } & Target \\
\hline & & Jmlh & $\%$ & jmlh & $\%$ & jmlh & $\%$ & $80 \%$ siswa mencapai \\
\hline $\begin{array}{l}\text { Pencapaian nilai } \\
70\end{array}$ & $\geq$ & 3 & 12,5 & 13 & 56,5 & 22 & 92 & nilai $\geq 70$ \\
\hline $\begin{array}{l}\text { Pencapaian nilai } \\
70\end{array}$ & $<$ & 21 & 87,5 & 10 & 43,5 & 2 & 8 & \\
\hline
\end{tabular}

Berdasarkan grafik di muka terjadi peningkatan hasil belajar siswa tentang pecahan. Peningkatan terjadi pada perolehan nilai siswa yang mencapai KKM. Pada siklus I, persentase jumlah siswa yang nilainya melebihi atau sama dengan 70 sebesar 12,5\%, pada siklus II mencapai 56,5\%, dan pada siklus III mencapai 92\%. Peningkatan yang terjadi cukup tinggi, yakni mencapai 43,5\% dari siklus I ke siklus II, dan $36 \%$ dari siklus
II ke siklus III. Rata-rata peningkatan sebesar $39,7 \%$. Sementara itu, hal sebaliknya terjadi pada perolehan nilai siswa yang kurang dari tujuh puluh 70. Pada siklus I nilai yang kurang dari 70 sangat tinggi, yaitu mencapai 87,5\%, sedangkan pada siklus II dan siklus menurun menjadi $43,5 \%$ dan $8 \%$.

\section{PEMBAHASAN}

Dari data tersebut dapat terlihat bahwa pada saat kinerja guru pada siklus I ke siklus 
Peningkatan Hasil Belajar Matematika Tentang Pecahan Melalui Pendekatan Matematika Realistik Ratih Purnamasari

II meningkat, kemudian keaktifan siswa juga meningkat, maka hasil belajar siswa pun meningkat. Hal yang sama juga terjadi pada siklus ke III. Hasil belajar siswa meningkat seiring dengan meningkatnya kinerja guru dan keaktifan siswa. Peningkatan itu terjadi karena pada siklus II guru telah sukses melaksanakan rencana perbaikan pada siklus I: diantaranya: Dalam aspek pemahaman konsep, pada saat berkeliling membimbing kelompok, guru akan mengarahkan siswa untuk mengaitkan konsep pecahan yang sedang dipelajari dengan konsep matematika yang lain dan dengan kehidupan sehari-hari. Misalkan dalam membagi kue tiruan guru memahamkan siswa bahwa dalam membagi kue harus sama. Supaya sama pada saat membagi, siswa bisa membagi dengan menghitung derajatnya (kue berbentuk lingkaran).

Selain itu, masih dalam aspek pemahaman konsep, guru mengkondisikan siswa agar menjelaskan jawaban kelompok dengan bantuan gambar pada papan tulis. Misalnya dengan cara meminta bantuan siswa yang bisa menggambar, untuk menggambarkan jawaban kelompok di papan tulis. Dalam aspek pembagian kelompok siswa terdiri atas siswa pandai dan kurang pandai serta adanya penjelasan di awal pembelajaran tentang tugas-tugas setiap anggota dalam kelompok.
Dalam aspek pengerjaan LKS, guru akan menjelaskan dengan pelan-pelan supaya siswa memahami maksud soal dengan baik dan memberikan kesempatan lebih banyak untuk bertanya dengan memberikan giliran kelompok untuk bertanya. Terakhir dalam aspek presentasi, guru akan menuntun siswa untuk berbicara di depan kelas dan lebih memotivasi siswa untuk bertanya, memberikan pendapat dan menyanggah jawaban teman dengan menunjuk tiap kelompok secara bergiliran dan guru memberikan contoh bagaimana cara melakukannya. Begitupula yang terjadi pada siklus III. Pada siklus III hasil belajar siswa juga meningkat, hal ini disebabkan karena guru telah mampu melaksanakan rencana perbaikan pada siklus II.

Untuk meyakinkan bahwa data yang diperoleh dari hasil observasi dan tes siklus, maka dilakukan perbandingan lagi dengan catatn lapangan dan hasil wawancara pada setiap siklus. Berdasarkan hasil catatan lapangan yang telah dibuat disimpulkan bahwa pada siklus I guru masih memiliki banyak kekurangan. Pada siklus II kekurangan itu berkurang dan pada siklus III kekurangan guru sangat sedikit. Sehingga dapat dikatakan meski guru tidak melaksanakan poin tersebut siswa tidak terlalu terpengaruh. Salah satu diantaranya 
adalah ketika guru tidak memberikan alat peraga berupa benda sebenarnya, karena pada pendekatan realistik memang alat peraga tidak harus benda sebenarnya, namun yang lebih penting adalah alat peraga itu bisa digunakan siswa untuk memahami konsep.

Hasil wawancara juga membuktikan bahwa data yang didapat dapat dipercaya, karena pada siklus I siswa menyatakan belum merasa siap dengan kerja kelompok dan belum terbiasa melaporkan jawaban. Namun pada siklus II siswa menyatakan sudah merasa nyaman dan pada siklus III siswa sudah mulai menikmati setiap tahapan dalam pembelajaran realsitik.

Dari triangulasi di atas dapat disimpulkan bahwa ada kesesuaian data antara hasil observasi, hasil tes siklus, catatn lapangan dan hasil wawancara terhadap siswa.

\section{SIMPULAN}

Berdasarkan hasil penelitian yang diperoleh, maka dapat disimpulkan bahwa: Pembelajaran matematika melalui pendekatan matematika realistik dapat meningkatkan hasil belajar matematika siswa tentang pecahan di kelas IV SDN Cilendek Timur 2 Kota Bogor. Pada siklus I, persentase jumlah siswa yang hasil belajar pecahannya mencapai atau melebih KKM sebanyak 12,5\%. Pada siklus II dan III persentasenya meningkat menjadi $56,5 \%$ dan $92 \%$.
Prinsip penggunaan konteks, dilaksanakan oleh guru dengan memberikan masalah tentang pecahan yang terkait dengan kehidupan sehari-hari siswa sehingga siswa mampu memahami masalah dengan baik.Prinsip penggunaan model, dilaksanakan guru dengan menyediakan alat peraga kue tiruan. Melalui kue tiruan siswa dapat mencari berbagai model penyelesaian masalah. Prinsip pemanfaatan hasil konstruksi siswa, dilakukan pada saat setiap siswa harus melaporkan jawaban kelompoknya. Setelah semua kelompok maju ke depan, siswa menyimpulkan model-model yang dihasilkan oleh semua kelompok yang kemudian diarahkan oleh guru menjadi model-model formal. Melalui aktivitas ini, selain siswa terlatih untuk berbicara di hadapan temantemannya, juga terlatih untuk menganalisis pendapat-pendapat temannya, sehingga mampu membuat sebuah kesimpulan. Prinsip interaktivitas muncul ketika guru mengkondisikan pembelajaran dalam bentuk kelompok, sehingga terjadi interaktivitas, baik siswa dengan kelompoknya, siswa dengan kelompok lain, maupun siswa dengan guru. Interaksi memungkinkan siswa memiliki banyak informasi yang akan menambah pengetahuan mereka. Prinsip keterkaitan dilaksanakan guru dengan mengarahkan siswa pada saat menyelesaikan masalah untuk mengaitkan masalah dengan konsep 
Peningkatan Hasil Belajar Matematika Tentang Pecahan Melalui Pendekatan Matematika Realistik Ratih Purnamasari

matematika lain yang telah mereka ketahui dan dengankehidupan sehari-hari. Hal ini berakibat positif terhadap kemampuan siswa dalam menyelesaikan masalah. Dengan mengaitkan pembelajaran dengan konsep lain dan dengan kehidupan sehari-hari siswa menjadi lebih mudah dalam mendapatkan penyelesaian masalah. Prinsip bimbingan dilaksanakan guru dengan senantiasa membimbing siswa dari mulai kegiatan pendahuluan sampai kegiatan penutup. Bimbingan dilakukan sampai siswa mendapatkan penyelesaian atas masalah yang diberikan. Bimbingan dari guru memungkinkan siswa terhindar dari rasa bosan. Sebaliknya dengan bimbingan dari guru siswa memiliki motivasi yang tinggi dalam menyelesaikan masalah.

\section{DAFTAR RUJUKAN}

Arikunto, Suharsimi. 2012. Dasar-Dasar Evaluasi Pendidikan Edisi 2. Jakarta: Bumi Akasara

Barnes, Patricia and Thomas E. Svarney, 2006. The Handy Math Answer Book. Visible Ink Press: USA

Dahar, Ratna Wilis. 2011. Teori-Teori Belajar \& Pembelajaran. Jakarta: Erlangga

Dimyati, dan Drs. Mudjiono. 2009. Belajar dan Pembelajaran. Jakarta: Rineka Cipta.

Dornyei, Zoltan. 2009. Motivational Strategies In The Language Classroom. USA: Cambridge University Press:
Fauzan, Ahmad. 2000. Applying realistic mathematics education (rme) in teaching geometry in indonesian primary schools. Dutch: Print Partners Ipskamp

Gunadijaya, Padmo, 2007 "Peningkatan Hasil Belajar Matematika dalam Pemahaman Bilangan Pecahan Melalui Pendekatan Realistik di Kelas III SDN Gedong 01 Pagi Pasar Rebo". Jakarta Timur, Skripsi. Jakarta:FIP UNJ

Heuvel-Panhuizen, Van den. 2000. "Mathematics education in the Netherlands: A guided tour". Freudenthal Institute Cd-rom for ICME9. Utrecht: Utrecht University:

Hopkins, David. 2011. Panduan Guru Penelitian Tindakan Kelas A Teacher's Guide To Classroom Research terjemahan Achmad Fawaid. Yogyakarta: Pustaka Pelajar

Karim, Muchtar A et al., 1996. Pendidikan Matematika 1. Malang: Depdikbud Dirjen Dikti

Kasbolah, Kasihani. 1999. Penelitian Tindakan Kelas (PTK). Malang: Depdikbud Dirjen Dikti Proyek Pendidikan Guru Sekolah Dasar

R, Soedjadi. "Pemanfaatan Realitas dan Lingkungan dalam Pembelajaran Matematika" Makalah pada Seminar Nasional "Realistic mathemathics education" (Surabaya: UNESA, 2001) (http//:pmatandy.blogspot.com/2008/12/ pembelajaran realistik)

Seifert, Kelvin dan Rosemary Sutton. 2009. Global Text Educational Psychology Second Edition (Jacobs Foundation: Zurich, Switzerland.

Shadiq, Fadjar dan Nur Amini Mustajab, 2010. Pembelajaran Matematika dengan Pendekatan Realistik. 
Yogyakarta:Kemendiknas

Dirjen

PMPTK PPPPTK matematika.

Sholekhah, Herawati. 2009. "Meningkatkan Hasil Belajar Matematika dengan Pendidikan Matematika Realistik Indonesia kelas II SD 3 Bantul'Bantul, Yogyakarta, Skripsi. Yogyakarta: FST UIN Sunankalijaga

Sudjana, Nana, 1989. Dasar-dasar Proses Belajar Mengajar. Bandung : Sinar Baru Algensido Offset

Suherman, Erman et al. 2003. Strategi Pembelajaran Matematika Kontemporer. Bandung: Jurusan Pendidikan Matematika, FPMIPA, UPI

Sukayati. Pecahan. 2003. Yogyakarta: Depdiknas dirjen Dikti

Sumitro, Nopem Kusumaningtyas. "Pembelajaran Matematika Realistik Untuk Pokok Bahasan Kesebangunan Di Kelas III SMP Negeri 3 Porong". Paradigma, Tahun XIII, No.25, JanuariJuni 2008.

Supriyatin, Kris Yuda. 2005. "Penerapan Pendekatan Realistik pada Pembelajaran Matematika di Kelas III SDN Tringgalis Cileungsi, Bogor, Jawa Barat, Skripsi. Jakarta:FIP UNJ

Suriasumantri, Jujun S. 2009. Filsafat Ilmu Sebuah Pengantar Populer. Jakarta: Pustaka Sinar Harapan,

Suwangsih. E, Tiurlina. 2006. Model Pembelajaran Matematika SD. Bandung: UPI PRESS

Ullya, Zulkardi, dan Ratu Ilma Putri. "Desain Bahan Ajar Penjumlahan Pecahan Berbasispendidikan Matematika Realistik Indonesia (PMRI) Untuk Siswa Kelas IV Sekolah Dasar Negeri 23 Indralaya". Jurnal Pendidikan Matematika, 4 (2). pp. 86-96. ISSN 1978-0044.

Verhage Heleen, \& Jan de Lange, "Mathematics education and assessment" Freudenthal Institute, The Netherlands. Amesa conference, 1-5 July 1996.

W. Eisner, Elliot. "Benjamin Bloom", Prospects: the quarterly review of comparative education (Paris, Unesco: International Bureu of Education), vol.XXX (3), September 2000.

Wardani, Kuswaya, dan Noehi. 2003. Penelitian Tindakan Kelas. Jakarta: Pusat Penerbitan Universitas Terbuka

Wijaya, Ariyadi. 2012. Pendidikan Matematika Realistik Suatu Alternatif Pendekatan Pembelajaran Matematika. Yogyakarta: Graha Ilmu

Winkel, W.S. 2002. Psikologi Pengajaran. Jakarta: Gramedia:

Yuliati, Siti Rohmi. "Matematika SD yang Dikehendaki Guru, Murid dan Orang tua, "Laporan Penelitian (Jakarta:LPM UNJ-Pemda 